\title{
Kualitas Semen dengan Berbagai Formulasi Pengencer Dasar Air Kelapa Hijau Selama Simpan Dingin pada Sapi Madura
}

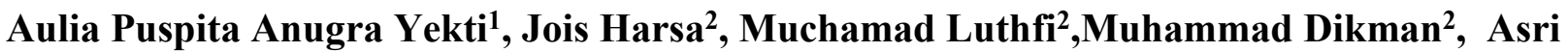 \\ Nurul Huda ${ }^{1}$, Kuswati ${ }^{1}$, Trinil Susilawati ${ }^{1 *}$
}

\author{
${ }^{1}$ Fakultas Peternakan Universitas Brawijaya \\ Jl. Veteran, Kota Malang, Jawa Timur 65145 \\ ${ }^{2}$ Loka Penelitian Sapi Potong Grati Pasuruan \\ J1. Pahlawan 2, Grati, Pasuruan, Jawa Timur 67184 \\ *Email Korespondensi: trinil_susilawati@yahoo.com
}

(Diterima: 25-8-2018; disetujui 20-9-2018)

\begin{abstract}
ABSTRAK
Inseminasi Buatan dengan menggunakan semen cair digunakan untuk daerah yang sulit nitrogen cair dan mempunyai kualitas yang lebih baik dari pada semen beku. Tujuan penelitian ini adalah untuk mengetahui kualitas berbagai bahan pengencer dasar air kelapa penyimpanan dingin $2-5^{\circ} \mathrm{C}$.Penelitian ini dilaksanakan di Loka Penelitian Sapi Potong Grati, Pasuruan. Semen yang digunakan berasal dari sapi madura sebanyak dua ekor, berumur 5 dan 3 tahun dan berat badan yaitu $397 \mathrm{~kg}$ dan 360,5 kg. Sapi madura ditampung seminggu 2 kali dengan motilitas $>70 \%$, sedangkan air kelapa yang digunakan adalah air kelapa hijau yang masih muda. Pengenceran semen cair dibagi menjadi 4 yaitu P0 (CEP-3 + $20 \%$ kuning telur) sebagai kontrol, P1 (air kelapa hijau $+20 \%$ kuning telur), P2 (P1 + 0,4\% putih telur + $1 \%$ fruktosa) dan $\mathrm{P} 3$ (P1 $+0,4 \%$ putih telur kuning telur $+2 \%$ fruktosa). Data dianalisis menggunakan uji Pearson's Chi Square dan Uji Deskriptif. Hasil penelitian menunjukkan motilitas spermatozoa sesuai standar SNI yaitu motilitas $>40 \%$ pada pengencer CEP-3 dapat disimpan selama hari ke-8 $(40,50 \pm 6,43 \%)$ sedangkan pada pengencer dasar air kelapa hijau pada P1, P2 dan P3 tidak menunjukkan perbedaan yang

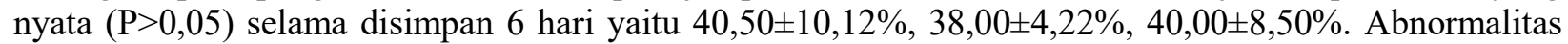
dari semua perlakuan menunjukan nilai $<20 \%$. Viabilitas didapatkan nilai tertinggi pada perlakuan

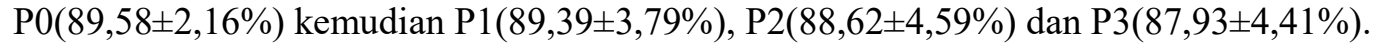

Kata kunci: CEP-3, semen cair, sapi madura, simpan dingin, air kelapa hijau

\begin{abstract}
Artificial Insemination using liquid semen is performed for areas that where liquid nitrogen is difficult to find and havng better quality than frozen semen. Purpose of this research was to investigate the quality on various coconut water base diluents on liquid semen of madura bull during cold storage of $2-5^{\circ} \mathrm{C}$. Research was conducted at Laboratory of Reproduction of Grati Beef Cattle Research Station, Pasuruan.Semen that is used comes from two madura bulls aged 5 and 3 years with body weight is $397 \mathrm{~kg}$ and $360.5 \mathrm{~kg}$. The semen was collected twice a week with motility $>70 \%$, and the coconut water used is unripe green coconut water. The research treatments were P0 (CEP-3 $+20 \%$ egg yolk) as control, P1 (unripe green coconut water $+20 \%$ egg yolk), $\mathrm{P} 2(\mathrm{P} 1+1 \%$ fructose $+0.4 \%$ egg white) and $\mathrm{P} 3(\mathrm{P} 1+0.4 \%$ egg white $+2 \%$ fructose). Data were analyzed using Pearson's Chi Square test and Descriptive Test. The results showed that the motility of spermatozoa was within Indonesian National Standard (SNI) with more than $40 \%$ motility in the CEP-3 diluent and it can be stored until the 8 th day $(40.50 \pm 6.43 \%)$. The basic diluents of green coconut water at P1, P2 and P3 was not significantly affected (P>0.05) until 6 days storing with the motility number average are $40.50 \pm 10.12 \%, 38.00 \pm 4.22 \%, 40,00 \pm 8.50 \%$. The abnormality of all treatments was under $20 \%$. The highest viability was showed by treatment P2 $(89.58 \pm 2.16 \%)$, followed by P4 $(89.39 \pm 3.79 \%)$, P3 $(88.62 \pm 4.59 \%)$ and the lowest was P4 $(87.93 \pm$ $4.41 \%)$.
\end{abstract}

Keywords: CEP-3, liquid semen, madura bull, cool storage, green coconut water 


\section{PENDAHULUAN}

Sapi madura merupakan salah satu plasma nutfah asli Indonesia yang memiliki produktivitas cukup baik. Peningkatan produktivitas sapi madura dapat dipercepat dengan penerapan teknologi reproduksi yaitu dengan inseminasi buatan (IB). IB merupakan salah satu teknologi yang tepat untuk diterapkan dipeternak yang keterbatasan pejantan unggul sehingga dapat dimanfaatkan secara maksimal (Rizal, 2009). Permasalahan penyimpanan semen beku yaitu harga nitrogen cair yang mahal dan mengalami penuruan fertilitas selama proses pembekuan dan proses thawing yang kurang tepat (Susilawati, 2016a; Salim et al., 2012). IB bisa diaplikasikan menggunakan semen beku dan semen cair. Aplikasi IB menggunakan semen cair dibutuhkan bahan pengencer yang mampu mempertahankan kualitas spermatozoa selama penyimpanan dingin (Audia et al., 2017). Hasil penelitian Saefudin et al. (2018) nilai conseptin rate hasil inseminasi buatan menggunakan semen cair dengan pengencer tris aminomethan kuning telur adalah 62,96\% lebih baik dari pada menggunakan semen beku $(59,25 \%)$ Akan tetapi dengan menggunakan pengencer CEP-3 hasilnya lebih rendah $51,85 \%$ dibandingkan $\mathrm{CR}$ pada IB menggunakan semen beku yaitu $62,96 \%$.

Bahan pengancer yang masih dalam pengembangan yaitu Cauda Epididymal Plasma 3 (CEP-3) merupakan pengembangan dari pengencer CEP-2 yaitu mengantikan Bovine Serum Albumin (BSA) dengan putih telur. Pengencer CEP-2 memiliki komposisi kimia seperti $\mathrm{NaCl}, \mathrm{KCl}, \mathrm{CaCl}_{2}\left(\mathrm{H}_{2} \mathrm{O}\right)_{2}, \mathrm{MgCl}_{2}\left(\mathrm{H}_{2} \mathrm{O}\right)_{2}$, $\mathrm{NaHCO}_{3}, \mathrm{NaH}_{2} \mathrm{PO}_{4}, \mathrm{KH}_{2} \mathrm{PO}_{4}$, fruktosa, sorbitol, bovine serum albumin (BSA), tris, gentamisin, penisilin, streptomicin dan asam sitrat (Ducha et al., 2013 dan Verberckmoes et al, 2004). Sesuai hasil penelitian Ratnawati et al. (2018) pengencer CEP-2 mendukung motilitas spermatozoa sehingga tahan disimpan dingin hingga hari kelima.

Bahan menggunakan air kelapa hijau muda sebagai pengencer lokal, diharapkan mampu meminimalisir kerusakan spermatozoa selama simpan dingin, tidak memerlukan nitrogen cair, dan dapat disimpan dalam suhu dingin. Menurut Salim et al. (2018), bahan pengencer yang digunakan harus murah dan tersedia di berbagai daerah. Kandungan yang terkandung di dalam air kelapa muda yaitu air $94,180 \mathrm{~g} / 100 \mathrm{~g}$, protein $0,120 \mathrm{~g} / 100 \mathrm{~g}$, lipid 0,073 $\mathrm{g} / 100 \mathrm{~g}, \mathrm{pH} 4,7$ dan mengandung beberapa ion yaitu $\mathrm{Fe}, \mathrm{P}, \mathrm{Na}, \mathrm{Zn} \mathrm{0,07,} \mathrm{Ca}, \mathrm{Cu}, \mathrm{Mn}$ serta di dalam air kelapa mengandung asam amino yaitu alanin, lisin, arginin, metionin, aspartat fenilalanin, glutamat, prolin, glisin, serin, histidin, treonin, isoleusin, valin dan leusin (Yong et al., 2009). Kurniawan et al. (2013) menjelaskan bahwa karbohidrat dalam air kelapa berupa glukosa dan fruktosa dapat dijadikan sumber energi bagi spermatozoa dan diharapkan mampu mempertahankan kehidupan spermatozoa. Pengenceran semen cair dengan air kelapa hijau muda pada kambing terbukti dapat mempertahankan motilitas spermatozoa selama dua hari dengan motilitas 48,33 $\pm 20,17 \%$ (Audia et al., 2017). Berdasarkan uraian di atas, perlu adanya penelitian lebih lanjut mengenai kualitas semen cair pada sapi madura dengan berbagai formulasi bahan pengencer dasar air kelapa hijau muda selama pendinginan $2-5^{\circ} \mathrm{C}$.

\section{MATERI DAN METODE}

\section{Materi}

Materi penelitian yaitu semen dari dua ekor sapi madura yang ada di Loka Penelitian Sapi Potong Grati Pasuruan. Semen yang digunakan berasal dari sapi madura sebanyak dua ekor, berumur 5 tahun dan 3 tahun dan berat badan yaitu $397 \mathrm{~kg}$ dan 360,5 kg. Penampungan semen sapi madura dilakukan dua kali dalam seminggu dengan motilitas lebih dari $70 \%$ menggunakan vagina buatan.

Persyaratan semen yaitu semen mempunyai motilitas individu $\geq 70 \%$, motilitas massa $2+$ dan abnormalitas $<20 \%$ (Susilawati, 2013; Ax et al., 2008). Bahan untuk menggantikan BSA yaitu menggunakan putih telur sebanyak $0,4 \%$ yaitu bagian putih telur yang encer (Solikah et al., 2016 dan Susilawati et al, $2016^{\text {b }}$ ). Kuning telur yang digunakan adalah kuning telur segar berasal dari ayam ras petelur berumur kurang dari 3 hari. Air kelapa hijau yang digunakan yaitu kelapa yang muda yang berumur 5-8 bulan yaitu sudah terdapat air dan daging kelapa (karnel) yang belum keras (Farapati et al., 2014).

\section{Metode}

Metode penelitian yang digunakan adalah metode eksperimental laboratorium dengan 4 perlakuan dan 10 ulangan. Perlakuan yang diuji coba yaitu P0 (CEP-3 $+20 \%$ kuning telur), P1 (air kelapa muda hijau $+20 \%$ kuning telur), $\mathrm{P} 2$ ( $\mathrm{P} 1+0,4 \%$ putih telur $+1 \%$ fruktosa), dan 
P3 (P1+0,4\% putih telur $+2 \%$ fruktosa). Variabel penelitian yang diamati yaitu persentase motilitas individu, persentase viabilitas, persentase abnormalitas, konsentrasi (jt/ml) dan total spermatozoa motil $(\mathrm{jt} / \mathrm{ml})$. Data dianalisis dengan uji statistik person's chi square pada hari yang terdekat dengan motilitas $40 \%$ dan $40 \mathrm{jt} / \mathrm{ml}$ serta uji deskriptif.

\section{Pembuatan CEP-3}

Tahap pembuatan pengencer CEP-3 adalah penyiapan bahan berupa fruktosa 55,0 $\mathrm{mmol} / \mathrm{l}$; Sorbitol $1,0 \mathrm{mmol} / \mathrm{l}$; asam sitrat 42,6 ; $\mathrm{NaCl} 15 \mathrm{mmol} / \mathrm{l} ; \mathrm{KCl} 7,0 \mathrm{mmol} / \mathrm{l} ; \mathrm{CaCl}_{2}\left(\mathrm{H}_{2} \mathrm{O}\right)$ $23,9 \mathrm{mmol} / 1 ; \mathrm{MgCl}_{2}\left(\mathrm{H}_{2} \mathrm{O}\right)_{2}$ 3,0 mmol/1; $\mathrm{NaHCO}_{3}$ $11,9 \mathrm{mmol} / \mathrm{l} ; \mathrm{NaH}_{2} \mathrm{PO} 48,0 \mathrm{mmol} / \mathrm{l} ; \mathrm{KH}_{2} \mathrm{PO}_{4} 20,0$ $\mathrm{mmol} / \mathrm{l}$; Tris $133,7 \mathrm{mmol} / \mathrm{l}$; gentacimicin $0,05 \mathrm{~g} / \mathrm{l}$; pH 6,6; penisilin $1000 \mathrm{IU}$; streptomisin $1 \mathrm{~g}$; putih telur 4 ml/1; Osm 250-350 mOsm. Bahan-bahan tersebut tanpa ditambahkan BSA dimasukan ke dalam erlenmeyer kapasitas 1 liter dan ditambahkan diiozine water sebanyak 1 liter kemudian diaduk mengunakan magnetic stirrer sampai merata (Susilawati et al., 2016 ${ }^{\mathrm{b}}$ ). $\mathrm{pH}$ diatur hingga memiliki $\mathrm{pH}$ 6-7 dan osmolaritas 250-350 mOsm (Ducha et al, 2013). Media kemudian disaring menggunakan membran milipor dengan ukuran (pore) 0,22 $\mu \mathrm{m}$. Putih telur yang encer dihisap menggunakan pipet sebanyak $0,4 \%$ atau $4 \mathrm{ml} / \mathrm{l}$. Pengambilan putih telur dilakukan saat akan digunakan (Sholikah et al., 2016; Susilawati et al., 2016 ). Media kemudian ditambah dengan $20 \%$ kuning telur dan dilakukan sentrifugasi pada $1500 \mathrm{rpm}$ sebanyak dua kali selama 30 menit kemudian diambil supernatan.

\section{Pembuatan Pengencer Air Kelapa Hijau Muda}

Tahap pembuatan pengencer air kelapa hijau muda yaitu air kelapa hijau muda diinaktifasi pada suhu $56^{\circ} \mathrm{C}$ selama 20 menit dan dilakuan penyaringan satu kali dengan kertas saring halus untuk memisahkan pertikel kasar serta dua kali dengan kertas saring whattman. Air kelapa hijau muda sebanyak $80 \mathrm{ml}$ dimasukan kedalam gelass ukur dan tambahkan $0,1 \mathrm{~g}$ penisilin; $0,1 \mathrm{~g}$ streptomisin; $0,1 \mathrm{~g} \mathrm{NaCHO} ; 1 \%$ fruktosa $(\mathrm{P} 2) ; 2 \%$ fruktosa $(\mathrm{P} 3) ; 0,4 \%$ putih telur; dan $20 \%$ kuning telur. Bahan pengencer dihomogenkan selama 10-15 menit dan disentrifugasi dua kali pada 1500 rpm selama 30 menit serta diambil supernatan.

\section{HASIL PENELITIAN}

Uji kualitas semen dilakukan setelah penampungan atau sebelum dilakukan proses pengenceran. Pemeriksaan makroskopis meliputi volume (ml), bau, warna, konsistensi dan $\mathrm{pH}$. Pemeriksaan miksroskopis meliputi motilitas massa, motilitas individu (\%), viabilitas (\%), abnormalitas (\%) dan konsentrasi (jt/ml). Rataan kualitas semen sapi madura dapat dilihat pada Tabel 1.

Warna semen sapi madura yang didapatkan yaitu putih susu dengan bau khas semen yang menunjukan bahwa semen tersebut dalam kondisi normal. Volume semen rata-rata selama penampungan adalah 4,75 $\pm 0,38 \mathrm{ml}$. Volume semen sapi bervariasi yaitu 5 atau $5-8$ $\mathrm{ml}$ per ejakulasi (Susilawati, 2013; Hopkins et al, 2003; Garner et al., 2008). Rata-rata $\mathrm{pH}$ semen sapi madura selama penampungan yaitu $6,60 \pm 0,12$. Nilai $\mathrm{pH}$ normal semen sapi yaitu 6,4-7,8 (Garner et al., 2008).

Konsistensi semen yang didapatkan yaitu sedang. Susilawati (2013) menyatakan bahwa konsistensi berkorelasi dengan konsentrasi spermatozoa, apabila konsistensi sedang maka konsentrasi spermatozoa yaitu $1000 \times 10^{6}-1500 \times 10^{6} / \mathrm{ml}$. Hasil pemeriksaan didapatkan motilitas massa $2+$, motilitas individu $70 \pm 0,00 \%$, viabilitas $90,60 \pm 2,86 \%$, abnormalitas $2,13 \pm 0,86 \%$ dan konsentrasi sebesar 1063,33 $\pm 69,44$ jt/ml. Susilawati (2013) menyatakan bahwa seman yang layak untuk diencerkan memiliki spermatozoa motil tidak kurang dari $65-70 \%$ dan abnormalitas $<20 \%$.

\section{Persentase Motilitas Spermatozoa Selama Penyimpanan Suhu $2-5^{\circ} \mathrm{C}$}

Motilitas atau daya gerak spermatozoa merupakan salah satu indikator yang mempengaruhi daya fertilitas spermatozoa untuk membuahi sel telur. Persentase spermatozoa diamati setiap 24 jam sekali dimulai pada hari pertama penyimpanan sampai hari ke-8 pada suhu $2-5^{\circ} \mathrm{C}$ sampai persentase motilitas sebesar $0 \%$. Rataan persentase motilitas spermatozoa ditampilkan pada Tabel 2.

Rataan persentase motilitas spermatozoa selama penelitian menunjukan bahwa pengenceran P0 sebagai kontrol dapat mempertahankan motilitas spermatozoa sampai 8 hari selama simpan dingin dengan motilitas $40,50 \pm 6,43 \%$. Perlakuan air kelapa mampu mempertahankan motilitas spermatozoa sampai hari ke-5 yaitu pada perlakuan P2 dengan 
Tabel 1. Rataan kualitas semen sapi madura

\begin{tabular}{lc}
\hline \multicolumn{1}{c}{ Pengamatan } & Rata-Rata \pm SD \\
\hline Uji Makroskopis & \\
Warna & Putih Susu \\
Konsistensi & Sedang \\
Bau & Khas Semen \\
Volume perejakulasi (ml) & $4,75 \pm 0,42$ \\
pH & $6,60 \pm 0,13$ \\
\hline Uji Makroskopis & ++ \\
Motilitas massa & $70,00 \pm 0,00$ \\
Motilitas individu (\%) & $90,60 \pm 2,86$ \\
Viabilitas (\%) & $2,13 \pm 0,94$ \\
Abnormalitas (\%) & $1063,33 \pm 76,07$ \\
Konsentrasi (jt/ml) & $744,33 \pm 53,25$ \\
Total spermatozoa yang motil $(\mathrm{jt} / \mathrm{ml})$ &
\end{tabular}

Tabel 2. Rataan persentase motilitas spermatozoa sapi madura pda berbagai perlakuan selama pendinginan.

\begin{tabular}{ccccc}
\hline \multirow{2}{*}{ Waktu Pengamatan } & \multicolumn{4}{c}{ Motilitas (\%) } \\
\cline { 2 - 5 } & P0 & P1 & P2 & P3 \\
\hline Hari 1 & $70,00 \pm 0,00$ & $70,00 \pm 0,00$ & $69,00 \pm 2,11$ & $68,50 \pm 1,58$ \\
Hari 2 & $69,00 \pm 3,16$ & $67,00 \pm 3,50$ & $67,50 \pm 3,54$ & $65,00 \pm 4,08$ \\
Hari 3 & $66,00 \pm 5,68$ & $63,50 \pm 6,69$ & $65,00 \pm 6,67$ & $59,00 \pm 6,58$ \\
Hari 4 & $63,00 \pm 5,37$ & $59,00 \pm 5,68$ & $59,50 \pm 5,99$ & $47,50 \pm 5,40$ \\
Hari 5 & $59,50 \pm 5,50$ & $47,50 \pm 7,91$ & $48,50 \pm 7,84$ & $40,00 \pm 8,50^{*}$ \\
Hari 6 & $55,00 \pm 4,71$ & $40,50 \pm 10,12^{*}$ & $38,00 \pm 4,22^{*}$ & $27,00 \pm 4,22$ \\
Hari 7 & $50,50 \pm 4,97$ & $27,00 \pm 5,87$ & $26,00 \pm 6,99$ & $12,00 \pm 6,75$ \\
Hari 8 & $40,50 \pm 6,43^{*}$ & $13,50 \pm 8,51$ & $11,00 \pm 6,58$ & \\
\hline
\end{tabular}

Keterangan: *) Nilai perlakuan yang diuji person's chi square

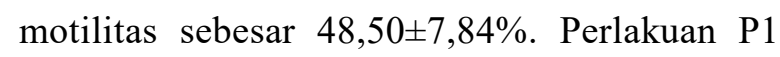
dan P3 bertahan sampai hari ke-6 dengan motilitas berturut-turut sebesar 40,0 $\pm 10,12 \%$ dan 40,00 $\pm 8,50 \%$. Persentase motilitas spermatozoa yang dapat digunakan untuk IB yaitu memiliki motilitas diatas 40\% (BSN, 2017).

Hasil analisis menggunakan pearson's chi square dengan nilai harapan $40 \%$ spermatozoa motil untuk diaplikasikan IB pada perlakuan P1 hari ke-6 menunjukan perbedaan yang sangat nyata $(\mathrm{P}<0,01)$ sedangkan pada $\mathrm{P} 0$ hari ke-8, P2 dan P3 hari ke-6 tidak berbeda nyata $(\mathrm{P}>0,05)$. Total spermatozoa motil yang dapat diaplikasikan untuk IB dengan nilai harapan motilitas spermatozoa $>40 \%$ yaitu perlakuan air kelapa hijau pada P1, P2 dan P3 dapat digunakan sampai 6 hari selama simpan dingin dan perlakuan CEP-3 yaitu P0 dapat digunakan IB selama 8 hari simpan dingin $2-5^{\circ} \mathrm{C}$.

Berdasarkan hasil tersebut maka bahan pengencer CEP-3 dengan putih telur mampu menggantikan BSA dalam mempertahankan motilitas spermatozoa pada semen cair sapi madura sampai hari ke-8.Bahan pengenceran air kelapa hijau muda mampu mempertahankan kualitas spermatozoa sampai 6 hari selama simpan dingin $2-5^{\circ} \mathrm{C}$. Hasil penelitian ini lebih baik dari Audia et al. (2017) bahwa dengan pengenceran air kelapa hijau muda pada kambing boerterbukti mampu mempertahankan motilitas spermatozoa sampai dua hari dengan motilitas sebesar 48,33 $\pm 20,17 \%$. Fruktosa di dalam air kelapa berfungsi sebagai sumber energi mampu mempertahankan tekanan osmotik dalam pengencer dan fruktosa sebagai krioproktektan ekstraseluler untuk melindungi selubung spermatozoa dari cold shock. Energi selain dari fruktosa, kuning telur mengandung sumber energi untuk spermatozoa, melindungi dari cold shock dan sebagai penyangga buffer (Atmaja et al., 2014).

\section{Persentase Viabilitas Spermatozoa Selama Penyimpanan Suhu $2-5^{\circ} \mathrm{C}$}

Viabilitas adalah salah satu indikator terpenting untuk menentukan kualitas spermatozoa selama pengenceran (Costa et al., 2016). Spermatozoa yang hidup ditandai dengan warna yang masih terang atau tidak menyerap warna sedangkan spermatozoa mati akan menyerap warna eosin negrosin dan spermatozoa 
Tabel 3. Rata-rata persentase viabilitas spermatozoa sapi madura pada berbagai perlakuan selama pendinginan

\begin{tabular}{ccccc}
\hline \multirow{2}{*}{ Waktu Pengamatan } & \multicolumn{4}{c}{ Viabilitas (\%) } \\
\cline { 2 - 5 } & P0 & P1 & P2 & P3 \\
\hline Hari 1 & $89,58 \pm 2,16$ & $88,62 \pm 4,59$ & $87,93 \pm 4,41$ & $89,39 \pm 3,79$ \\
Hari 2 & $88,04 \pm 2,82$ & $86,78 \pm 4,45$ & $87,06 \pm 4,06$ & $88,03 \pm 4,08$ \\
Hari 3 & $86,39 \pm 4,89$ & $86,30 \pm 4,98$ & $86,33 \pm 5,47$ & $85,43 \pm 4,00$ \\
Hari 4 & $84,11 \pm 3,05$ & $83,76 \pm 7,26$ & $83,87 \pm 5,78$ & $82,56 \pm 6,86$ \\
Hari 5 & $81,88 \pm 6,07$ & $81,78 \pm 7,83$ & $78,42 \pm 8,23$ & $80,45 \pm 7,93$ \\
Hari 6 & $79,23 \pm 9,14$ & $74,02 \pm 4,55$ & $73,01 \pm 3,40$ & $72,23 \pm 2,44$ \\
Hari 7 & $76,92 \pm 8,66$ & $73,08 \pm 5,20$ & $71,28 \pm 3,50$ & $72,37 \pm 4,00$ \\
Hari 8 & $71,24 \pm 5,27$ & $65,95 \pm 6,20$ & $66,09 \pm 6,85$ & $67,05 \pm 6,91$ \\
\hline
\end{tabular}

Tabel 4. Rata-rata persentase abnormalitas spermatozoa sapi madura pada berbagai perlakuan selama pendinginan.

\begin{tabular}{ccccc}
\hline \multirow{2}{*}{ Waktu Pengamatan } & \multicolumn{4}{c}{ Abnormalitas (\%) } \\
\cline { 2 - 4 } & P0 & P1 & P2 & P3 \\
\hline Hari 1 & $3,14 \pm 1,29$ & $3,55 \pm 1,37$ & $3,81 \pm 2,61$ & $3,07 \pm 1,21$ \\
Hari 2 & $3,91 \pm 2,52$ & $3,61 \pm 1,56$ & $3,75 \pm 1,12$ & $3,15 \pm 0,93$ \\
Hari 3 & $3,25 \pm 1,79$ & $4,03 \pm 2,28$ & $3,86 \pm 1,57$ & $4,37 \pm 1,52$ \\
Hari 4 & $4,04 \pm 1,48$ & $3,81 \pm 2,01$ & $3,26 \pm 2,34$ & $4,01 \pm 1,90$ \\
Hari 5 & $4,71 \pm 2,09$ & $4,68 \pm 2,15$ & $4,42 \pm 1,95$ & $4,15 \pm 1,94$ \\
Hari 6 & $3,66 \pm 1,69$ & $4,07 \pm 1,96$ & $4,83 \pm 1,93$ & $4,62 \pm 1,56$ \\
Hari 7 & $3,53 \pm 1,38$ & $3,01 \pm 2,21$ & $3,16 \pm 1,00$ & $3,32 \pm 1,32$ \\
Hari 8 & $3,75 \pm 2,02$ & $4,66 \pm 3,94$ & $3,63 \pm 1,65$ & $4,08 \pm 1,35$ \\
\hline
\end{tabular}

berwarna sebagian dianggap mati akibat rusaknya membran sel spermatozoa (Susilawati, 2013). Rataan persentase viabilitas spermatozoa ditampilkan pada Tabel 3.

Persentase viabilitas mengalami penurunan selama penyimpanan dan nilai viabilitas pada penyimpana hari ke- 8 yang $>70 \%$ yaitu pada pengencer P0 $(71,24 \pm 5,27 \%)$, sedangkan persentase viabilitas menggunakan pengencer air kelapa sampai hari ke-7didapatkan persentase viabilitas paling tinggiyaitu berturutturut P1 $(73,08 \pm 5,20 \%), \mathrm{P} 2(71,28 \pm 3,50 \%)$ dan P3 $(72,37 \pm 4,00 \%)$. Persentase viabilitas terus mengalami penurunan selama simpan dingin. Persentase viabilitas spermatozoa selama penyimpanan lebih tinggi dari persentase motilitas individu spermatozoa, karena spermatozoa yang tidak bergerak belom tentu mati atau spermatozoa masih dorman karena thawing yang kurang tepat. Menurunya viabilitas spermatozoa yang hidup dipengaruhi oleh naiknya suhu didalam refrigator, hal ini akibat aktivitas membuka dan menutup pintu refrigator selama melakukan pengecekan viabilitas serta metabolisme spermatozoa yaitu menghasilkan asam laktat yang menjadi salah satu faktor penghambat dan dapat menurunkan nilai viabilitas spermatozoa (Costa et al., 2016).

\section{Persentase Abnormalitas Spermatozoa Selama Penyimpanan Suhu $2-5^{\circ} \mathrm{C}$}

Abnormalitas terdapat dua macam yaitu abnormalitas primer dan sekunder.Abnormalitas primer meliputi kepala tanpa ekor, ekor ganda, kerusakan akrosom, macrocephalus, microcephalus, ekor melintang, dan ekor pyriform. Abnormalitas sekunder meliputi ekor melipat, butiran sisa sitoplasma, kepala tanpa ekor (putus), ataupun ekor tanpa kepala (Susilawati, 2013). Rataan persentase abnormalitas spermatozoa sapi madura pada berbagai perlakuan selama pendinginan dapat dilihat pada Tabel 4.

Nilai abnormalitas menunjukan bahwa angka abnormalitas tertinggi berada pada penyimpanan hari ke-5 yaitu pada perlakuan $\mathrm{P} 0$ sebesar $4,71 \pm 2,09 \%$ dan diikuti oleh perlakuan P1, P2 dan P3 dengan nilai abnormalitas berturutturut sebesar $4,68 \pm 2,15 \%, 4,42 \pm 1,95 \%$ dan $4,15 \pm 1,94 \%$. Rataan nilai abnormalitas yang didapatkan masih dibawah $20 \%$ artinya masih baik digunakan untuk IB. Hal ini sesuai dengan pernyataan Susilawati (2013) menyatakan bahwa abnormalitas yang baik yaitu dibawah $20 \%$. Abnormalitas pada spermatotoza kemungkinan disebabkan oleh reaksi cold shock dan penyimpanan dingin (Susilawati, 2016 ${ }^{\mathrm{b}}$ ). 
Tabel 5. Rata-rata persentase total spermatozoa motil sapi madura pada berbagai perlakuan selama pendinginan.

\begin{tabular}{|c|c|c|}
\hline Perlakuan & Waktu & Rata-rata total spermatozoa motil(jt/ml) \\
\hline P0 & Hari ke-8 & $46,50 \pm 6,41$ \\
\hline P1 & Hari ke-6 & $46,20 \pm 13,95$ \\
\hline $\mathrm{P} 2$ & Hari ke-6 & $42,10 \pm 5,54$ \\
\hline P3 & Hari ke-6 & $44,15 \pm 10,69$ \\
\hline Nilai Harapan & & $40,00 \mathrm{jt} / \mathrm{ml}$ \\
\hline
\end{tabular}

\section{Persentase total spermatozoa motil selama penyimpanan suhu $2-5^{\circ} \mathrm{C}$}

Penilaian kualitas total spermatozoa

motil bertujuan untuk melihat peluang keberhasilan fertilisasi ditentukan oleh spermatozoa motil progresif. Susilawati (2013) menyatakan bahwa total spermatozoa motil dapat dihitung dengan mengalikan volume semen dengan konsentrasi kemudian dikalikan dengan persentase motilitas individu spermatozoa. Standar total spermatozoa motil yang digunakan dalam inseminasi pada sapi adalah $40 \mathrm{juta} / \mathrm{ml}$. Rataan persentase total spermatozoa motil pada berbagai perlakuan selama pendinginan dapat dilihat pada Tabel 5 .

Analisis statistik dengan chi square nilai harapan $40 \mathrm{juta} / \mathrm{ml}$ untuk diaplikasikan IB. Perlakuan pada air kelapa yaitu P1 $(46,20 \pm 13,95$ $\mathrm{jt} / \mathrm{ml})$ dan $\quad \mathrm{P} 3 \quad(44,15 \pm 10,69 \quad \mathrm{jt} / \mathrm{ml}) \quad$ pada penyimpanan hari ke-6 menunjukan perbedaan yang sangat nyata $(\mathrm{P}<0,01)$. Perlakuan $\mathrm{P} 2$ selama penyimpanan hari ke-6 tidak menunjukan perbedaan nyata $(\mathrm{P}>0,05)$ artinya pada pengencerah tersebut sama dengan nilai harapan $40 \mathrm{jt} / \mathrm{ml}$ namun masih biasa diaplikasikan untuk IB dengan total spermatozoa $42,10 \pm 5,54 \mathrm{jt} / \mathrm{ml}$ dan total spermatozoa motil pada perlakuan P0 $(46,50 \pm 6,41 \mathrm{jt} / \mathrm{ml}) \quad$ sebagai kontrol pada penyimpanan hari ke-8 menunjukan perbedaan nyata $(\mathrm{P}<0,05)$ artinya bahwa perlakuan CEP-3 dapat diaplikasikan untuk IB selama simpan dingin 8 hari.

Pengenceran CEP-3 yaitu mensubstitusi BSA dengan putih telur mampu mempertahankan motilitas spermatozoa sampai 8 hari selama simpan dingin. Pengenceran CEP yang dilakukan sama dengan pengamatan Ducha et al (2013) pada pengenceran CEP-2 dengan penambahan $20 \%$ kuning telur sebagai pelindung dari cold shock pada sapi limosin mampu mempertahankan motilitas spermatozoa sampai hari ke-8 dengan nilai rataan motilitas sebesar 44,25 $\pm 3,92 \%$. Pengenceran dengan berbagai formulasi bahan dasar air kelapa hijau muda dapat diaplikasikan untuk IB selama 6 hari selama penyimpanan dingin. Metabolisme fruktosa lebih efisien dalam menghasilkan energi. Ketersediaan oksigen didalam pengencer selama penyimpanan apabila tidak mencukupi, maka metabolisme spermatozoa akan berjalan secara anaerob, namun apaila metabolisme dalam keadaan anaerob menghasilkan asam laktat yang mengakibatkan racun dan akan mengakibatkan kematian bagi spermatozoa (Kurniawan et al, 2013).

\section{KESIMPULAN}

Pengencerperlakuan terbaik air kelapa hijau yaitu pengencer P1 (80\% air kelapa hijau muda $+20 \%$ kuning telur) tanpa adanya penambahan bahan lain dan dapat mempertahankan kualitas semen cair selama 6 hari dengan nilai motilitas individu sebesar $40,50 \pm 10 \%$.Pengencer sebagai kontrol yaitu P0 (CEP-3 $+20 \%$ kuning telur), dapat disimpan sampai 8 hari dengan motilitas sebesar $40,50 \pm 6,43 \%$, dengana adanya penambahan putih telur sebanyak $0,4 \%$ dapat menggantikan BSA sehingga mampu mempertahankan motilitas selama simpan dingin $2-5^{\circ} \mathrm{C}$.

Saran bahan pengencer yang baik untuk diaplikasi IB yaitu pengencer P0 (CEP-3+20\% kuning telur) dapat disampan dan digunakan sampai 8 hari selama simpan dingin. Formulasi bahan pengencer terbaik pada air kelapa hijau muda yaitu perlakuan P1 (air kelapa hijau muda $+20 \%$ kuning telur) dapat disimpan dan aplikasikan untuk IB sampai 6 hari selama simpan dingin.

\section{UCAPAN TERIMA KASIH}

Ucapan terimakasih pada KEMENRISTEK DIKTI melalui dana penelitian PUPTN dan Loka Penelitian Sapi Potong Grati Pasuruan yang memberikan fasilitas penelitian. 


\section{DAFTAR PUSTAKA}

Atmaja, W.K, M.K Budiasa \& Wayan. 2014. Bebas penambahan fruktosa mempertahankan motilitas dan daya hidup spermatozoa kalkun yang disimpan pada suhu $4^{\circ} \mathrm{C}$. Indonesia Medicus Veterinus 3(4):318-327

Audia, R.P., M.A., Salim, N. Isnaini, \& T. Susilawati. 2017. Pengaruh perbedaan kematangan air kelapa hijau sebagai bahan pengencer yang ditambah $10 \%$ kuning telur terhadap kualitas semen cair kambing boer. J. Ternak Tropika 18(1):58-68.

Ax, R., M. Dally, B. Didion, R. Lenz, C. Love, D. Varner, Hafez, \& M. Bellin. 2008. Semen evaluation in reproduction in farm animal $7^{\text {th }}$ edition. Edited by $\mathrm{Hafez}$, E.S.E. Co. Director.Reproductive Health Kiawah Island. South Carolina. USA. pp 365-370.

BSN. 2017. Semen Beku-Bagian 1: Sapi. Badan Standarisasi Nasional. SNI 4869-1:2017. BSN. Jakarta

Costa, N.D., T. Susilawati, N. Isnaini, \& M.N. Ihsan. 2016. Effect of different dilution materials usage on indonesian peranakan ongole bull sperm quality during cooling process. IAJPS 3(4):379-385.

Ducha, N., T. Susilawati, Aulanni'am, \& S. Wahyuningsih. 2013. Motilitas dan viabilitas spermatozoa sapi limousin selama penyimpanan pada refrigerator dalam pengencer CEP-2 dengan suplementasi kuning telur. Jurnal Kedokteran Hewan 7 (1):5-8.

Farapti \& S. Sayogo. 2014. Air kelapa muda pengaruhnya terhadap tekanan darah. CDK 41(12):896-900.

Garner, D.L. \& E.S.E. Hafez. 2008. Spermatozoa and seminal plasma in reproduction in farm animals 7th edition. Blackwell Publishing Professional. USA. pp 96109.

Hopkins, S.M. \& L. E. Evans. 2003. Artificial Insemination. In: M.H. Pineda. Mc.Donald Veterinary Endocrynology and Reproduction. $5^{\text {th }}$ ed. Blackwell publishing. USA. pp 341-375
Kurniawan, I.Y., F. Basuki, \& T. Susilawati. 2013. Penambahan air kelapa dan gliserol pada penyimpanan sperma terhadap motilitas dan fertilitas spermatozoa ikan mas (Cyprinus carpio). Journal of Aquaqulture Management and Technology 2(1):51-56.

Ratnawati, D., N. Isnaini, \& T. Susilawati. 2018. Character motility of liquid semen on ongole crossbred (PO), bali and madura bulls with different diluent at cold storage. Asian Jr. Microbiol. Biotech. Env. Sc. 20(1):21-28

Rizal, M. 2009. Daya hidup spermatozoa epididimis sapi Bali yang dipreservasi pada suhu $3-5^{\circ} \mathrm{C}$ dalam pengencer tris dengan konsentrasi laktosa yang berbeda. Jurnal Ilmu Ternak dan Veteriner 14(2):142-149.

Saifudin,M., N. Isnaini., A.P.A.Yekti, \& T. Susilawati. 2018. Tingkat keberhasilan inseminasi buatan menggunakan semen cair menggunakan media pengencer tris ainomethan kuning telur pada sapi peranakan ongole. Jurnal Ternak Tropika 19(1):60-65

Salim, A., A.P.A. Yekti, Kuswati, \& T. Susilawati. 2018. Perbedaan keberhasilan inseminasi buatan menggunakan semen beku dan cair menggunakan pengencer CEP-3+kuning telur pada sapi persilangan ongole. Jurnal Ternak Tropika 19 (1):66-72.

Salim, M.A., T. Susilawati, \& S. Wahyuningsih. 2012. Pengaruh metode thawing terhadap kualitas semen beku sapi bali, sapi madura dan sapi PO. Agripet 12(2):1420.

Sholikah, N., N. Isnaini., A.P.A. Yekti, \& T. Susilawati. 2016. Pengaruh penggantian bovine serum albumin (BSA) dengan putih telur pada pengencer CEP-2 terhadap kualitas semen sapi peranakan ongole pada suhu penyimpanan $3-5^{\circ} \mathrm{C}$. Jurnal Ilmu-Ilmu Peternakan 26(1):7-15.

Susilawati, T. 2013. Pedoman Inseminasi Buatan Pada Ternak. UB Press. . Malang.

Susilawati T., N. Isnaini, A.P.A. Yekti, I. Nurjanah, Errico, \& N.D. Costa. 2016a. Keberhasilan inseminasi buatan menggunakan semen beku dan semen 
cair pada sapi peranakan ongole. Jurnal Ilmu-Ilmu Peternakan 26 (3):14-19.

Susilawati T., F.E. Wahyudi, I. Anggraeni, N. Isnaini, \& M.N. Ihsan. 2016 ${ }^{\text {b }}$ Penggantian bovine serum albumin pada pengencer CEP-2 dengan serum darah sapi dan putih telur terhadap kualitas semen cair sapi limousin selama pendinginan. Jurnal Kedokteran Hewan 10(2):98-102.

Verberckmoes, S., A.V. Some., J. Dewulf., I.D. Pauw, \& A. Kruif. 2004. Storage of fresh bovine semen in a diluent based on the ionic composition of cauda epididymal plasma. Journal of Reprod. Dom. Anim. 39(6):1-7.

Yong, J.W.H., L. Ge, Y.F. Ng \& S.N. Tan. 2009. The chemical composition and biological properties of coconut (Cocos nucifera L.) water. Molecules 14:5144-5164. 